\title{
Anaerofilum pentosovorans gen. nov., sp. nov., and Anaerofilum agile sp. nov., Two New, Strictly Anaerobic, Mesophilic, Acidogenic Bacteria from Anaerobic Bioreactors $\dagger$
}

\author{
GERHARD ZELLNER, ${ }^{1 *}$ ERKO STACKEBRANDT, ${ }^{2,3}$ DAGMAR NAGEL, ${ }^{2}$ PAUL MESSNER, ${ }^{4}$ \\ NORBERT WEISS, ${ }^{3}$ AND JOSEF WINTER ${ }^{5}$
}
Institut für Mikrobiologie, Universität Hannover, D-30167 Hannover, ${ }^{1}$ Institut für Allgemeine Mikrobiologie, Universität Kiel, D-24118 Kiel, ${ }^{2}$ Deutsche Sammlung von Mikroorganismen und Zellkulturen, D-38124 Braunschweig, ${ }^{3}$ and Institut für Ingenieurbiologie und Biotechnologie des Abwassers, D-76128 Karlsruhe, ${ }^{5}$ Germany, and Zentrum für Ultrastrukturforschung and Ludwig Boltzmann-Institut für Molekulare Nanotechnologie, Universität für Bodenkultur, A-1180 Vienna, Austria ${ }^{4}$

\begin{abstract}
Strictly anaerobic, gram-positive, nonsporing, thin rod-shaped organisms whose cells were 0.2 to 0.6 by 3 to $6 \mu \mathrm{m}$ were isolated from a Hoechst Biohochreaktor (strain $\mathrm{Fae}^{\mathrm{T}}$ [T $=$ type strain]) and from the biofilm population of a fixed-film reactor treating sour whey (strain $F^{T}$ ). Strain $F^{\mathbf{T}}$ was vigorously motile during early logarithmic growth by means of peritrichously inserted flagella, while strain Fae $^{\mathrm{T}}$ was seldom motile and usually possessed no flagella. During the stationary growth phase both strains formed spheroplasts. The temperature optimum was close to $37^{\circ} \mathrm{C}$ (temperature range for growth, $\geq 17$ to $<45^{\circ} \mathrm{C}$ ) and the pH optimum was 7.0 to 7.4 (pH range, 6.5 to 8.0) for both strains. The two organisms grew chemoorganotrophically on a number of mono- and disaccharides, including glucose and xylose; yeast extract was required for growth. The principal fermentation products from glucose included lactate, acetate, ethanol, formate, and $\mathrm{CO}_{2}$. $\mathrm{Hydrogen}$ was not generated. The $G+C$ contents of the DNAs of strains Fae $^{T}$ and $F^{T}$ were 55 and 54.5 mol\%, respectively. The cell wall architecture was typical of gram-positive bacteria; the cells had an extraordinarily thin type A3 $\boldsymbol{\alpha}^{\prime}$ peptidoglycan layer containing muramic acid. Analysis of $16 \mathrm{~S}$ ribosomal DNA sequences of the two new isolates demonstrated that they represent members of a new genus of bacteria in Clostridium cluster IV of the domain Bacteria and that the misclassified organism Fusobacterium prausnitzii and Clostridium leptum are among their closest relatives. The names Anaerofilum pentosovorans gen. nov., sp. nov. (type strain, strain Fae [= DSM 7168]) and Anaerofilum agile sp. nov. (type strain, strain F [= DSM 4272]) are proposed.
\end{abstract}

The genus Clostridium represents a large variety of species that occur ubiquitously in anaerobic habitats, utilize a broad spectrum of substrates $(2,9)$, and belong to the low-G+Ccontent subphylum of the phylum of gram-positive Bacteria (30). The genus Clostridium, however, is not coherent phylogenetically, and representatives of various genera, including both spore-forming and non-spore-forming organisms, are found in the radiation of Clostridium species $(2,3,17,21,22)$. In this paper we report the isolation of two acidogenic, nonsporing rods that have high DNA $\mathrm{G}+\mathrm{C}$ contents from anaerobic high-rate bioreactor consortia; phylogenetically, these organisms belong to Clostridium cluster IV as defined by Collins et al. (3), and we propose the new genus Anaerofilum for them.

\section{MATERIALS AND METHODS}

Isolation. Strain $\mathrm{Fae}^{\mathrm{T}}(\mathrm{T}=$ type strain) was isolated from a Biohochreaktor at the Hoechst Chemical Co. in Kelsterbach, Frankfurt, Germany. Sludge from the wastewater reactor was serially diluted in $120-\mathrm{ml}$ serum bottles containing $20 \mathrm{ml}$ of prereduced medium with a gaseous atmosphere consisting of $80 \% \mathrm{~N}_{2}$ and $20 \%$ $\mathrm{CO}_{2}(300 \mathrm{kPa})$. The dilutions were streaked onto agar plates containing the same medium supplemented with $0.5 \%$ (wt/vol) glucose and $2 \%$ (wt/vol) agar (Oxoid Wesel, Germany) in an anaerobic chamber and were incubated in a stainless steel anaerobic jar (1) at $37^{\circ} \mathrm{C}$ with a gas atmosphere containing $80 \% \mathrm{~N}_{2}$ and $20 \% \mathrm{CO}_{2}(200 \mathrm{kPa})$. After 14 days colonies of strain $\mathrm{Fae}^{\mathrm{T}}$ that were 1 to $2 \mathrm{~mm}$ in diameter and white with lobate margins and raised centers were picked and transferred into serum bottles. Culture purity was checked microscopically. Strain $\mathrm{F}^{\mathrm{T}}$ was isolated from an anaerobic biofilm population in a fixed-film

* Corresponding author. Mailing address: Institut für Mikrobiologie, Universität Hannover, Schneiderberg 50, D-30167 Hannover, Germany. Phone: 49511762 4718. Fax: 495117625287.

$\dagger$ This work is dedicated to the 65th birthday of Hans Diekmann, Hannover, Germany. reactor treating sour whey $(32,33)$ that had been inoculated with anaerobic sewage sludge from the municipal sewage treatment plant of Regensburg, Germany.

Reference strain. Bifidobacterium longum DSM 20219 was obtained from the Deutsche Sammlung von Mikroorganismen und Zellkulturen, Braunschweig, Germany.

Media. Media were prepared by using the anaerobic technique of Balch et al. (1), and strains were grown in prereduced medium in pressurized serum bottles as described previously (33). B. longum was grown in MRS medium (5).

Transmission electron microscopy. Photomicrographs of thin sections and freeze-etched cell preparations were taken with a Philips model EM 301 electron microscope at $80 \mathrm{kV}(26)$

Cell wall composition. Cell walls were purified and analyzed by the method of Schleifer and Kandler (25). Total cell wall acid hydrolysates $\left(4 \mathrm{~N} \mathrm{HCl}, 100^{\circ} \mathrm{C}\right.$, $16 \mathrm{~h}$ ) were subjected to a quantitative amino acid and amino sugar analysis with a Biotronik model L 6001 amino acid analyzer. The structure of the murein was deduced from the molar ratio of the amino acids and the peptide pattern found in partial acid hydrolysates $\left(4 \mathrm{~N} \mathrm{HCl}, 100^{\circ} \mathrm{C}, 45 \mathrm{~min}\right)$.

Analytical procedures. Growth was determined turbidimetrically at $578 \mathrm{~nm}$. The organic acids, alcohols, acetoin, diacetyl, and hydrogen contents were determined with a gas chromatograph equipped with a flame ionization detector or a thermal conductivity detector (33). The succinate content was determined by gas chromatography after derivatization to the corresponding methyl ester as described by Holdeman et al. (12). The glucose, xylose, and formate contents were determined spectrophotometrically $(16,20)$. The $\mathrm{D}-(-)$ - and L- $(+)$-lactate contents were determined enzymatically (11). Fructose-6-phosphate phosphoketolase activity was assayed as described previously (24). The presence of catalase was determined by dropping $4 \% \mathrm{H}_{2} \mathrm{O}_{2}$ onto a colony after incubation in air for $0.5 \mathrm{~h}(12)$.

DNA base composition and DNA-DNA hybridization. Strain $\mathrm{F}^{\mathrm{T}}$ and $\mathrm{Fae}^{\mathrm{T}}$ DNAs were isolated, and the $G+C$ contents of these DNAs were determined by the thermal denaturation method and by high-performance liquid chromatography (HPLC) $(19,31)$. The DNAs used for DNA hybridization experiments were isolated and levels of DNA-DNA homology were calculated from renaturation rates as described previously $(4,13,14)$.

Sequence analysis of $16 \mathrm{~S}$ rDNA and phylogenetic analysis. The $16 \mathrm{~S}$ ribosomal DNA (rDNA) sequences of the new strains were compared with the sequences in the $16 \mathrm{~S}$ rDNA database for members of the Clostridium-Bacillus subphylum of gram-positive bacteria (18). Similarity values were transformed into phylogenetic 

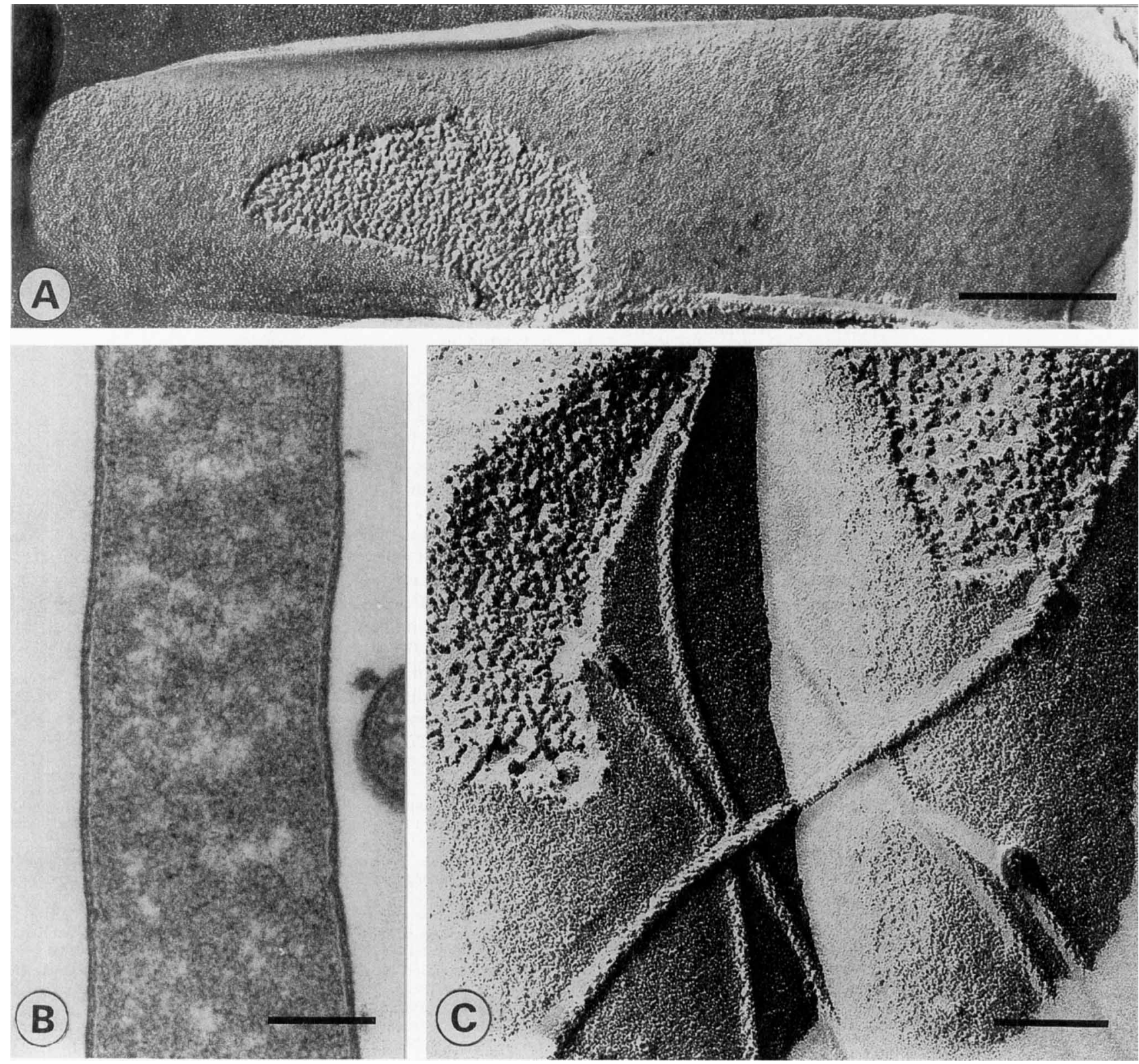

FIG. 1. Electron micrographs of cells of strains $\mathrm{Fae}^{\mathrm{T}}$ and $\mathrm{F}^{\mathrm{T}}$. (A) Freeze-etched preparation of strain $\mathrm{Fae}^{\mathrm{T}}$. Bar $=0.25 \mu \mathrm{m}$. $(\mathrm{B})$ Thin section of strain $\mathrm{F}^{\mathrm{T}}$. Bar $=$ $0.2 \mu \mathrm{m}$. (C) Freeze-etched preparation of strain $\mathrm{F}^{\mathrm{T}}$ showing insertion sites of flagella. Bar $=0.1 \mu \mathrm{m}$.

distance values that compensated for multiple substitutions at any given site in the sequence (15). The least-squares distance method of De Soete (6) and the neighbor-joining and maximum-likelihood programs in the PHYLIP package (8) were used to construct phylogenetic dendrograms (23). To calculate bootstrap values, 300 trees were analyzed by using the NJFIND and NJBOOT programs.

Nucleotide sequence accession numbers. The sequences of the 16S rDNAs of strains $\mathrm{Fae}^{\mathrm{T}}$ and $\mathrm{F}^{\mathrm{T}}$ have been deposited in the EMBL database under accession numbers X97852 and X98011, respectively.

\section{RESULTS}

Morphology and cell wall. The cells of strains $\mathrm{F}^{\mathrm{T}}$ and $\mathrm{Fae}^{\mathrm{T}}$ were gram-positive, straight rods $(0.2$ to 0.6 by 3 to $6 \mu \mathrm{m})$ that occurred singly or in pairs and occasionally formed filaments up to $30 \mu \mathrm{m}$ long. Both strains produced spheroplasts after depletion of the substrate. No S-layer outside the cell wall of strain $\mathrm{Fae}^{\mathrm{T}}$ was observed on freeze-fracture electron micro- graphs (Fig. 1a). Cells of strain $\mathrm{Fae}^{\mathrm{T}}$ were seldom motile. In contrast, strain $\mathrm{F}^{\mathrm{T}}$ was motile during logarithmic growth. The cell wall architecture of strain $\mathrm{F}^{\mathrm{T}}$ was gram positive, but the wall had an unusually thin murein sacculus (Fig. 1b). A freezeetched preparation of intact cells of strain $\mathrm{F}^{\mathbf{T}}$ revealed highly structured flagella, but no S-layers were observed (Fig. 1c). Neither strain formed spores.

Growth conditions. The organisms did not grow aerobically and did not grow in MRS medium under nitrogen gas. Neither organism formed catalase, and both organisms grew only in prereduced media. Strains $\mathrm{F}^{\mathrm{T}}$ and $\mathrm{Fae}^{\mathrm{T}}$ required $0.2 \%$ yeast extract for growth, while the presence of Trypticase peptone and $61 \mathrm{mM}$ sodium acetate had no influence on growth. Strain $\mathrm{Fae}^{\mathrm{T}}$ grew optimally on glucose with a broad temperature optimum of 25 to $40^{\circ} \mathrm{C}$ and a doubling time of 2.5 to $5 \mathrm{~h}$. The 
optimal growth temperature of strain $\mathrm{F}^{\mathrm{T}}$ was around $37^{\circ} \mathrm{C}$, and the shortest doubling time observed was $16.7 \mathrm{~h}$. Strains $\mathrm{Fae}^{\mathrm{T}}$ and $\mathrm{F}^{\mathrm{T}}$ did not grow at $\leq 15$ and $\geq 45^{\circ} \mathrm{C}$ (growth temperature range, $\geq 17$ to $<45^{\circ} \mathrm{C}$ ). The $\mathrm{pH}$ optimum was 7.0 to $7.4(\mathrm{pH}$ range, 6.5 to 8.0 ) for both strains. $\mathrm{NaCl}$ had no influence on the growth of strain Fae up to a concentration of $400 \mathrm{mM}$.

Physiology. Strains $\mathrm{Fae}^{\mathrm{T}}$ and $\mathrm{F}^{\mathrm{T}}$ were grown in $120 \mathrm{ml}$-serum bottles under a $80 \% \mathrm{~N}_{2}-20 \% \mathrm{CO}_{2}$ gas phase $(300 \mathrm{kPa})$ at $37^{\circ} \mathrm{C}$ and $100 \mathrm{rpm}$ with several substrates at a concentration of 0.2 or $0.5 \%$ (wt/vol or vol/vol). Both strains grew on cellobiose, fructose, galactose, glucose, maltose, ribose, trehalose, and xylose. In addition, arabinose, mannose, and sorbose were utilized by strain $\mathrm{Fae}^{\mathrm{T}}$, while $\mathrm{D}$-salicin and $\mathrm{D}$-sorbitol were utilized by strain $\mathrm{F}^{\mathrm{T}}$. Neither strain utilized lactose, melibiose, raffinose, rhamnose, sucrose, methanol, ethanol, 1-propanol, citrate, fumarate, malate, succinate, L- $(+)$-lactate, cellulose, starch, xylan, pectin A, L-glutamate, L-tryptophan, L-phenylalanine, Lalanine, or L-glycine. Growth of strain $\mathrm{F}^{\mathrm{T}}$ on all substrates was poor compared with growth of strain $\mathrm{Fae}^{\mathrm{T}}$. Very weak growth of strain $\mathrm{F}^{\mathrm{T}}$ occurred on L-valine and L-isoleucine. Furthermore, 2-propanol, 2-butanol, L-aspartate, L-valine, glutaric acid, and monomethylamine were not utilized by strain $\mathrm{Fae}^{\mathrm{T}}$, and 1-butanol, glycerol, and esculin were not utilized by strain $\mathrm{F}^{\mathrm{T}}$. Sulfate was not reduced by either strain.

The principal products of glucose fermentation formed by strain $\mathrm{Fae}^{\mathrm{T}}$ were lactic acid [both isomers but the $\mathrm{L}-(+)$-lactate isomer was dominant], ethanol, acetate, formate, and $\mathrm{CO}_{2}$, as well as a small amount of 2,3-butandiol. Strain $\mathrm{F}^{\mathrm{T}}$ fermented glucose to $\mathrm{L}-(+)$-lactate, acetate, formate, ethanol, and $\mathrm{CO}_{2}$. Neither organism produced hydrogen or hydrogen sulfide from sulfate. Traces of isobutyrate and isovalerate were found in culture supernatants of strain $\mathrm{F}^{\mathrm{T}}$, and these compounds presumably were derived from amino acid degradation (degradation of valine and isoleucine, respectively). Propionate, butyrate, succinate, acetoin, diacetyl, methanol, and 2-propanol were not fermentation products of strains $\mathrm{Fae}^{\mathrm{T}}$ and $\mathrm{F}^{\mathrm{T}}$. The presence of hydrogen in the gas atmosphere $(300 \mathrm{kPa}$ of $80 \%$ $\mathrm{H}_{2}-20 \% \mathrm{CO}_{2}$ ) neither inhibited growth of strain $\mathrm{F}^{\mathrm{T}}$ nor altered the pattern of fermentation products (data not shown). Fructose-6-phosphate phosphoketolase activity, the key enzyme activity of the "bifido-shunt," was not detected in crude extracts of strain $\mathrm{F}^{\mathrm{T}}$ (with $B$. longum used as a positive control).

Murein composition and peptidoglycan structure. The total acid hydrolysates of the cell walls of strains $\mathrm{Fae}^{\mathrm{T}}$ and $\mathrm{F}^{\mathrm{T}}$ were identical and contained $N$-acetylmuramic acid, $N$-acetylglucosamine, and the amino acids glycine (Gly), glutamic acid (Glu), lysine (Lys), serine (Ser), and alanine (Ala) at a molar ratio of 1:1:1: $<1:<1$. In partial acid hydrolysates the following peptides were detected by thin-layer chromatography: L-GlyD-Glu, L-Lys-L-Ser, L-Lys-D-Ala, and L-Ser-D-Ala. The lactyl group of the muramic acid was esterified with glycine. The interpeptide linkage was formed by L-serine, which was identified by chiral chromatography because of the inability of the amino acid analyzer to distinguish between L-Ser and D-Ser. The data obtained are consistent with peptidoglycan type $\mathrm{A} 3 \alpha^{\prime}$.

G $+\mathbf{C}$ contents of DNAs. The base composition of the DNA of strain $\mathrm{F}^{\mathrm{T}}$ was $54.5 \mathrm{~mol} \% \mathrm{G}+\mathrm{C}$ (average of two determinations; thermal denaturation method). The $\mathrm{G}+\mathrm{C}$ content of the DNA of strain $\mathrm{Fae}^{\mathrm{T}}$ was $55 \mathrm{~mol} \%$ (as determined by HPLC).

Phylogenetic position. The 16S rDNA analysis indicated that there is a high level of relatedness (level of sequence similarity, 99.2\%) between strains Fae ${ }^{\mathrm{T}}$ (= DSM 7168 ${ }^{\mathrm{T}}$ ) and $\mathrm{F}^{\mathrm{T}}$ (= DSM $4272^{\mathrm{T}}$ ) (Fig. 1). The corresponding level of DNA-DNA similarity was $48 \%$, as determined by the renaturation method. Phylogenetically, these two strains are members of Clostridium

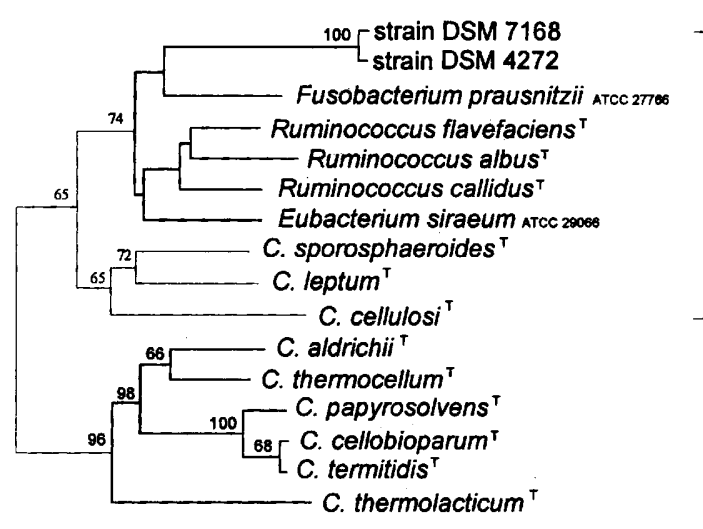

Cluster IV

$5 \%$

FIG. 2. Phylogenetic positions of strains $\mathrm{Fae}^{\mathrm{T}}$ and $\mathrm{F}^{\mathrm{T}}$ within the ClostridiumBacillus subphylum (cluster IV). Bar $=5 \%$ sequence divergence. C., Clostridium. Numbers refer to bootstrap values.

cluster IV, as defined by Collins et al. (3). This cluster contains several Clostridium species, including Clostridium sporosphaeroides, Clostridium cellulosi, and C. leptum (levels of $16 \mathrm{~S}$ rDNA similarity with the new isolates, 88 to $90 \%$ ), as well as members of the genus Ruminococcus (Ruminococcus albus, Ruminococcus flavefaciens, Ruminococcus callidus, and Ruminococcus bromii; levels of $16 \mathrm{~S}$ rDNA similarity with the new isolates, 87 to $89 \%$ ) and members of the genus Eubacterium (Eubacterium plautii, Eubacterium sireaum, and Eubacterium desmolans; levels of $16 \mathrm{~S}$ rDNA similarity with the new isolates, 85 to $88 \%$ ) (Fig. 2) (21). The nearest neighbor of the new isolates is the misclassified strain $F$. prausnitzii ATCC 27766, although this organism is only remotely related (level of $16 \mathrm{~S}$ rDNA similarity, $90 \%$ ).

\section{DISCUSSION}

Phylogenetically; strains $\mathrm{F}^{\mathrm{T}}$ and $\mathrm{Fae}^{\mathrm{T}}$ belong to the Clostridium-Bacillus branch of the Bacteria. These two strains are closely related to each other (level of $16 \mathrm{~S}$ rDNA sequence similarity, 99.2\%), but despite the high level of $16 \mathrm{~S}$ rDNA similarity they may belong to distinct species (27). The level of DNA-DNA homology obtained for strains $\mathrm{Fae}^{\mathbf{T}}$ and $\mathrm{F}^{\mathbf{T}}(48 \%)$ is far below the threshold value of $70 \%$ recommended for species delineation (28). This justifies the creation of two separate species, because DNA-DNA homology takes precedence over 16S rDNA sequence similarity (27). The closest relatives of the new strains were found to be the misclassified organism $F$. prausnitzii ATCC 27766 and $C$. leptum, both of which have high DNA G + C contents (52 to 57 and 51 to $52 \mathrm{~mol} \%$, respectively) $(9,10,12)$ and both of which belong to cluster IV defined by Collins et al. (3). The $\mathrm{G}+\mathrm{C}$ contents of Fusobacterium species usually range from 26 to $34 \mathrm{~mol} \%$ (10). The $\mathrm{G}+\mathrm{C}$ contents of $R$. flavefaciens, $R$. albus, and $R$. callidus range from 39 to $46 \mathrm{~mol} \%$ (7), while the $\mathrm{G}+\mathrm{C}$ content of $E$. siraeum is 45 mol\% (12). Phylogenetically, the new organisms were about equally related to $C$. leptum and $C$. sporosphaeroides, both of which are members of "family 3" proposed by Collins et al. (3). However, the latter organism has a DNA G+C content of only 27 mol\%. In contrast, Clostridium quercicolum, which has a high DNA G+C content $(52$ to $54 \mathrm{~mol} \%)(9,12)$, was phylogenetically more distantly related to the new organisms (data not shown).

Morphologically, strains $\mathrm{Fae}^{\mathbf{T}}$ and $\mathrm{F}^{\mathrm{T}}$ were thin, straight, 
rod-shaped organisms, similar to C. leptum, which forms nonmotile, slightly curved cells and, rarely, oval spores. In contrast, the new organisms never formed spores, either after starvation or after heat treatment. Freshly isolated strains may not form spores (2). The new strains also exhibited a phylogenetic relationship to some Ruminococcus species and $E$. siraeum, which also do not form endospores. Thin sections of strain $\mathrm{Fae}^{\mathrm{T}}$ and $\mathrm{F}^{\mathrm{T}}$ preparations revealed a gram-positive cell wall profile, but the murein layers were extraordinarily thin, which explains why a positive Gram stain reaction was observed only during the early logarithmic growth phase. Older cultures exhibited gramnegative staining. Clostridium spp., as well as $C$. sporosphaeroides, have typical peptidoglycan topology with direct crosslinking of the meso-diaminopimelic acid $(25,29)$. The cell walls of strains $\mathrm{F}^{\mathrm{T}}$ and $\mathrm{Fae}^{\mathrm{T}}$ were peptidoglycan type $\mathrm{A} 3 \alpha^{\prime}$ walls and were similar to the cell walls of $C$. leptum, which contain a lysine-serine-glycine type of peptidoglycan (K-type peptidoglycan containing Lys-Ser-D-Glu) (29).

The fermentation products of strains $\mathrm{F}^{\mathrm{T}}$ and $\mathrm{Fae}^{\mathrm{T}}$ included lactic acids, ethanol, acetate, formate, and $\mathrm{CO}_{2}$. Strains $\mathrm{Fae}^{\mathrm{T}}$ and $\mathrm{F}^{\mathrm{T}}$ had to be differentiated physiologically from $F$. prausnitzii, $R$. flavefaciens, $R$. albus, $R$. callidus, $E$. siraeum, and $C$. leptum of cluster IV.F. prausnitzii did not utilize or only weakly utilized mono-, di-, and oligosaccharides, but the fermentation products were butyrate, formate, and lactate, as well as minor amounts of succinate; thus, $F$. prausnitzii is distinct from the new organisms (10). E. siraeum produced acetate, ethanol, and large amounts of $\mathrm{H}_{2}$, as well as traces of lactic, butyric, and succinic acids (12). C. leptum produced mainly acetate, as well as some ethanol and large quantities of hydrogen in peptoneyeast extract-maltose medium (12). C. sporosphaeroides, however, produced acetate, butyrate, and traces of propionate as fermentation products $(9,12)$.

The chemotaxonomic and molecular taxonomic features of strains $\mathrm{F}^{\mathrm{T}}$ and $\mathrm{Fae}^{\mathrm{T}}$ described above justified creation of a novel genus, the genus Anaerofilum.

Description of Anaerofilum gen. nov. Anaerofilum (An.ae.ro' fi. lum. Gr. pref. an, not; Gr. n. aer, air; Gr. adj. anaero, absence of air, referring to the anaerobic mode of living; M.L. n. filum, thread, referring to the very thin rod-shaped cells; M.L. n. Anaerofilum, anaerobic thin rods). Gram-positive, non-sporeforming, straight, thin rods. The cell wall architecture is typical of gram-positive bacteria. A murein layer is present, but is unusually thin. The peptidoglycan of strain $\mathrm{F}^{\mathrm{T}}$ contains $\mathrm{L}$ glycine, D-glutamate, L-lysine, and D-alanine. The interpeptide linkage is formed by L-serine. Cells are fragile and form spheroplasts during the stationary growth phase. Cells are motile and peritrichously flagellated or nonmotile. Obligately anaerobic. No microaerophilic or aerobic growth occurs. Catalase negative. Strains are mesophilic (temperature range, $\geq 17$ to $<45^{\circ} \mathrm{C}$ ). Chemoorganotrophic. A variety of mono- and disaccharides are fermented. The major fermentation products from glucose include lactic acid, acetate, ethanol, formate, 2,3-butandiol, and carbon dioxide. Propionate, isobutyrate, isovalerate, succinate, diacetyl, and acetoin are not produced from glucose. Sulfate is not reduced. Hydrogen and hydrogen sulfide are not produced. Isobutyrate and/or isovalerate may be produced by amino acid degradation (isoleucine, valine). The $\mathrm{G}+\mathrm{C}$ contents of the DNAs of known strains range from 54 to $55 \mathrm{~mol} \%$. The habitats are anaerobic sewage sludge of municipal and industrial wastewater treatment plants. Two species are known, Anaerofilum pentosovorans and Anaerofilum agile; $A$. pentosovorans is designated the type species because it grows better.

Description of Anaerofilum pentosovorans sp. nov. Anaerofilum pentosovorans (pen.to.so'vo.rans. M.L. n. pentosum, sugar with five carbon atoms; L.v. vorare, to eat; L. adj. pentosovorans, fermenting pentose). Cells are thin, straight, long rods that are 0.2 to 0.6 by 3 to $6 \mu \mathrm{m}$. Cells are seldom motile. Spheroplasts are formed during the stationary growth phase. Colonies on glucose-containing agar plates are white and translucent with lobate margins and raised centers. The $\mathrm{G}+\mathrm{C}$ content is $55 \mathrm{~mol} \%$ (as determined by HPLC). The habitat is an industrial wastewater bioreactor at the Hoechst Chemical Co. in Kelsterbach, Frankfurt, Germany. The type strain is strain Fae (= DSM 7168).

Description of Anaerofilum agile sp. nov. Anaerofilum agile (a'gi.le. M.L. adj. agile, rapidly moving). Cells are thin, long rods that are 0.2 to 0.6 by 3 to $6 \mu \mathrm{m}$. Cells are motile by means of several peritrichously inserted flagella. Spheroplasts are formed during the stationary growth phase. Colonies on glucose-containing agar plates are circular, slightly convex, white, and translucent. The $\mathrm{G}+\mathrm{C}$ content is $54.5 \mathrm{~mol} \%$ (as determined by the thermal denaturation method). The habitat is a methane-producing fixed-film reactor digesting sour whey which was inoculated with sewage sludge from the municipal sewage treatment plant of Regensburg, Germany. The type strain is strain F (= DSM 4272).

\section{ACKNOWLEDGMENTS}

Determination of the $\mathrm{G}+\mathrm{C}$ content of the DNA of strain $\mathrm{Fae}^{\mathrm{T}}$ by $\mathrm{K}$. Bleicher and determination of the serine configuration of the peptidoglycan by P. Schumann (Deutsche Sammlung von Mikroorganismen und Zellkulturen, Jena, Germany) are gratefully acknowledged.

\section{REFERENCES}

1. Balch, W. E., G. E. Fox, L. J. Magrum, C. R. Woese, and R. S. Wolfe. 1979. Methanogens: reevaluation of a unique biological group. Microbiol. Rev. 43:260-296.

2. Cato, E. P., and E. Stackebrandt. 1989. Taxonomy and phylogeny, p. 1-26. In N. P. Minton and D. J. Clarke (ed.), Clostridia. Plenum Press, New York.

3. Collins, M. D., P. A. Lawson, A. Willems, J. J. Cordoba, J. FernandezGarayzabal, P. Garcia, J. Cai, H. Hippe, and J. A. E. Farrow. 1994. The phylogeny of the genus Clostridium: proposal of five new genera and eleven new species combinations. Int. J. Syst. Bacteriol. 44:812-826.

4. De Ley, J., H. Cattoir, and A. Reynaerts. 1970. The quantitative measurement of DNA hybridisation from renaturation rates. Eur. J. Biochem. 12: 133-142.

5. De Man, J. C., M. Rogosa, and M. E. Sharpe. 1960. A medium for the cultivation of lactobacilli. J. Appl. Bacteriol. 23:130-135.

6. De Soete, G. 1983. A least squares algorithm for fitting additive trees to proximity data. Psychometrika 48:621-626.

7. Ezaki, T., H. Oyaizu, and E. Yabuuchi. 1992. The anaerobic gram-positive cocci, p. 1879-1892. In A. Balows, H. G. Trüper, M. Dworkin, W. Harder, and K.-H. Schleifer (ed.), The prokaryotes, 2nd ed., vol. II. Springer, New York.

8. Felsenstein, J. 1993. PHYLIP (phylogeny inference package), version 3.5c. University of Washington, Seattle.

9. Hippe, H., J. R. Andreesen, and G. Gottschalk. 1992. The genus Clostridium-nonmedical, p. 1800-1866. In A. Balows, H. G. Trüper, M. Dworkin, W. Harder, and K.-H. Schleifer (ed.), The prokaryotes, 2nd ed., vol. II. Springer, New York.

10. Hofstad, T. 1992. The genus Fusobacterium, p. 4114-4126. In A. Balows, H. G. Trüper, M. Dworkin, W. Harder, and K.-H. Schleifer (ed.), The prokaryotes, 2nd ed., vol. IV. Springer, New York.

11. Hohorst, H. J. 1970. L(+)-Lactatbestimmung mit Lactat-Dehydrogenase und NAD, p. 1425-1429. In H. U. Bergmeyer (ed.), Methoden der enzymatischen Analyse. Verlag Chemie, Weinheim, Germany.

12. Holdeman, L. V., E. P. Cato, and W. E. C. Moore (ed.). 1977. Anaerobe laboratory manual, 4th ed. Anaerobe Laboratory, Virginia Polytechnic Institute and State University, Blacksburg.

13. Huss, V. A. R., H. Festl, and K.-H. Schleifer. 1983. Studies on the spectrophotometric determination of DNA hybridization from renaturation rates. Syst. Appl. Microbiol. 4:184-192.

14. Jahnke, K.-D. 1992. BASIC computer program for evaluation of spectroscopic DNA renaturation data from GILFORD SYSTEM 2600 spectrophotometer on a PC/XT/AT type personal computer. J. Microbiol. Methods 15:61-73.

15. Jukes, T. H., and C. R. Cantor. 1969. Evolution of protein molecules, p. 21-132. In H. N. Munro (ed.), Mammalian protein metabolism. Academic Press, New York. 
16. Lang, E., and H. Lang. 1972. Spezifische Farbreaktion zum direkten Nachweis der Ameisensäure. Z. Anal. Chem. 260:8-10.

17. Lawson, P. A., P. Llop-Perez, R. A. Hutson, H. Hippe, and M. D. Collins. 1993. Towards a phylogeny of the clostridia based on 16S rRNA sequences. FEMS Microbiol. Lett. 113:87-92.

18. Maidak, B. L., N. Larsen, M. J. McCaughey, R. Overbeck, G. J. Olsen, K. Fogel, J. Blandy, and C. R. Woese. 1994. The Ribosomal Database Project. Nucleic Acids Res. 22:3483-3487.

19. Marmur, J., and P. Doty. 1962. Determination of the base composition of deoxyribonucleic acid from its thermal denaturation temperature. J. Mol. Biol. 5:109-118.

20. Miller, G. L. 1959. Use of dinitrosalicylic acid reagent for determination of reducing sugar. Anal. Chem. 31:426-428.

21. Rainey, F. A., and P. H. Janssen. 1995. Phylogenetic analysis by 16 S ribosomal DNA sequence comparison reveals two unrelated groups of species within the genus Ruminococcus. FEMS Microbiol. Lett. 129:69-74.

22. Rainey, F. A., and E. Stackebrandt. 1993. 16S rDNA analysis reveals phylogenetic diversity among the polysaccharolytic clostridia. FEMS Microbiol. Lett. 113:125-128.

23. Saitou, N., and M. Nei. 1987. The neighbor-joining method: a new method for reconstructing phylogenetic trees. Mol. Biol. Evol. 4:406-425.

24. Scardovi, V., and L. D. Trovatelli. 1969. New species of bifid bacteria Apis mellifica L. and Apis indica F. A contribution to the taxonomy and biochemistry of the genus Bifidobacterium. Zentralbl. Bakteriol. Parasitenkd. Infektionskr. Hyg. Abt. 2 123:64-88.

25. Schleifer, K. H., and O. Kandler. 1972. Peptidoglycan types of bacterial cell walls and their taxonomic implications. Bacteriol. Rev. 36:407-477.
26. Sleytr, U. B., P. Messner, and D. Pum. 1988. Analysis of crystalline bacterial surface layers by freeze-etching, metal shadowing, negative staining and ultrathin sectioning. Methods Microbiol. 20:29-60.

27. Stackebrandt, E., and B. M. Goebel. 1994. Taxonomic note: a place for DNA-DNA reassociation and 16S rRNA analysis in the present species definition. Int. J. Syst. Bacteriol. 44:846-849.

28. Wayne, L. G., D. J. Brenner, R. R. Colwell, P. A. D. Grimont, O. Kandler, M. I. Krichevsky, L. H. Moore, W. E. C. Moore, R. G. E. Murray, E. Stackebrandt, M. P. Starr, and H. G. Trüper. 1987. Report of the Ad Hoc Committee on Reconciliation of Approaches to Bacterial Systematics. Int. J. Syst. Bacteriol. 37:463-464.

29. Weiss, N., K.-H. Schleifer, and O. Kandler. 1981. The peptidoglycan types of Gram-positive anaerobic bacteria and their taxonomic implications. Rev. Inst. Pasteur Lyon 14:3-12.

30. Woese, C. R., E. Stackebrandt, T. J. Macy, and G. E. Fox. 1985. A phylogenetic definition of the major eubacterial taxa. Syst. Appl. Microbiol. 6:143151.

31. Zellner, G., E. Stackebrandt, P. Messner, B. J. Tindall, E. Conway de Macario, H. Kneifel, U. B. Sleytr, and J. Winter. 1989. Methanocorpusculaceae fam. nov., represented by Methanocorpusculum parvum, Methanocorpusculum sinense spec. nov. and Methanocorpusculum bavaricum spec. nov. Arch. Microbiol. 151:381-390.

32. Zellner, G., P. Vogel, H. Kneifel, and J. Winter. 1987. Anaerobic digestion of whey and whey permeate with suspended and immobilized complex and defined consortia. Appl. Microbiol. Biotechnol. 27:306-314.

33. Zellner, G., and J. Winter. 1987. Analysis of a highly efficient methanogenic consortium producing biogas from whey. Syst. Appl. Microbiol. 9:284-292. 